been mainly responsible for sending in reports and the carcases or the portions of them forwarded to the Museum. The Royal Scottish Museum, the Department of Lands and Fisheries and the National Museum of Ireland, Dublin, and many private individuals interested in marine mammals have also rendered valuable help. As a further aid to all those who are interested, the British Museum (Natural History) has re-issued a pamphlet on the subject (British Museum (Natural History). Guide for the Identification and Reporting of Stranded Whales, Dolphins, Porpoises and Turtles on the British Coasts. By F. C. Fraser and H. W. Parker. Second edition. Pp. viii +42 . (London: British Museum (Natural History), 1953.) 2s.). The purpose of the pamphlet is to combine in one publication the advice relating to stranded whales, dolphins and turtles issued by the Museum in the past. It is also hoped that the figures and descriptions may help those concerned to distinguish the various species with greater certainty and so add to the interest already demonstrated in this work.

\section{Rats and Mice}

IN an attempt to reduce the appalling waste of food each year in Great Britain, the Ministry of Agriculture and Fisheries has revised its original bulletin on rats and mice on the farm (Ministry of Agriculture and Fisheries. Bulletin No. 30: Rats and Mice on the Farm. Eighth edition. Pp. iv + $17+8$ plates. (London: H.M. Stationery Office, 1953.) 28. net). The bulletin is an attempt to explain in simple language the fundamental principles of rodent control, and to provide the farmer with sufficient information to enable him to take effective preventive and control measures. As a means of identification, details are given of the common rat, ship rat and house mouse, while some useful hints are provided on the means of proofing new and old buildings against attacks by these rodents. Means of using poison baits, gases and traps are described, as are the farmer's statutory responsibilities under the Prevention of Damage by Pests Act of 1949.

\section{Milk Pasteurization}

A PROFUSELY illustrated monograph on milk pasteurization has just been published in the World Health Organization monograph series (World Health Organization. Monograph Series No. 14: Milk Pasteurization, Planning, Plant Operation and Control. By Dr. H. D. Kay, J. R. Cuttell, H. S. Hall, Dr. A. T. R. Mattick and A. Rowlands. Pp. 204. (Geneva: World Health Organization; London : H.M. Stationery Office, 1953.) 10 Swiss francs; 12s. 6d. ; 2.50 dollars). The monograph, which has been published jointly by the Food and Agriculture and the World Health Organizations of the United Nations, has been written by British authorities and contains a digest of the most up-to-date information on the various stages of milk pasteurization, from the planning of a suitable pasteurization plant to the drawing-up of legislation concerning the handling and treatment of milk. The first essential in milk pasteurization is a satisfactorily designed and wellequipped dairy building. The problems involved in determination of the site, choice of processing methods, planning the layout of the building, and selection of construction materials are fully discussed in the monograph, while the three most generally accepted methods of milk pasteurization and the type of plant required for each are described. The operation of the plant is considered in detail, and standards for prepasteurization and pasteurization procedures are clearly defined.

\section{Phosphate Absorption and Utilization by Barley}

SINCE the processes of absorption and translocation are closely interrelated in the intact plant, the nutrient content of roots is both determined by the balance of these processes, and is a factor determining their rates. The value of using radioactive tracers in exploring these phenomena is emphasized and exemplified by R. Scott Russell and R. P. Martin in a study of the absorption and utilization of phosphate by young barley plants (J. Exp. Bot., 4, 10, 108; 1953). Two problems were selerted for an initial investigation, namely, the relationship between the external concentration and the rate of absorption of phosphate in actively growing plants; and the relationship between the amount absorbed and the pattern of distribution. The experiments were carried out in water culture with radioactive phosphate supplied over a range of $0 \cdot 0003-30 \cdot 0$ p.p.m. phosphorus. When the external concentration of phosphate is reduced below 10 p.p.m. phosphorus, the proportion of the absorbed phosphate found in the shoots is markedly reduced. Plants treated with low concentrations of phosphates lose recently absorbed phosphate to the outer medium when transferred to phosphate-free solutions: plants treated with higher concentrations lose a smaller proportion of recently absorbed phosphate. Different balances of other nutrients do not appear to affect the general relationship between the absorption and distribution of phosphate, though quantitative changes occur. The authors conclude that phosphate retention in the roots induced by dilute media is a direct consequence of the small quantity of phosphate entering the roots and is not attributable to the effects of other ions which may be simultaneously absorbed.

\section{Maintenance of Physical Standards}

A Tw0-DAY symposium on "Recent Developments and Techniques in the Maintenance of Standards" was held at the 'National Physical Laboratory, Teddington, during May 21-22, 1951 (see Nature, $168,594 ; 1951)$, and the full proceedings, containing the individual papers presented and the discussions which followed them, have now been published (pp. $100+15$ plates. London: H.M.S.O., $1952 ; 4 s$. $6 d$. net). The contents are divided into six sections dealing with primary load standards, the standard of length, standards of radioactive isotopes, temperature, the standard of light and standards of frequency. Each section consists of two papers, one by a delegate from overseas and the other by a member of the staff of the Laboratory. Research physicists will be interested in the new methods and apparatus proposed or constructed for attaining and improving the extremely high order of accuracy and precision of measurement of the fundamental physical standards; and, in addition, teachers of physics will welcome this up-to-date account of, for example, the light-wave standard of length, or measurements of the velocity of light.

National Museum of Wales : Report for 1951-52.

THE forty-fifth annual report of the National: Museum of Wales, covering the year 1951-52, is as. usual an interesting and far from stereotyped docu- 